\title{
Structure and diversity of native bacterial communities in soils contaminated with polychlorinated biphenyls
}

\author{
Adalberto Zenteno-Rojas' ${ }^{1}$ Esperanza Martínez-Romero², Daniel Castañeda-Valbuena', \\ Clara Ivette Rincón-Molina', Víctor Manuel Ruíz-Valdiviezo', Rocío Meza-Gordillo, \\ Juan José Villalobos-Maldonado ${ }^{1}$, Miguel Ángel Vences-Guzmán and Reiner Rincón-Rosales ${ }^{1 *}$
}

\begin{abstract}
Persistent organic pollutants (POPs) such as polychlorinated biphenyls (PCBs) are a group of high-risk synthetic substances for human and environmental health. Currently, the study of sites contaminated by the spillage of equipment PCBs containing have been considered targeted areas for the study of bacterial communities with potential for PCBs degradation. There in isolation of bacterial strains is vital for use in biodegradable processes, such as bacterial bioaugmentation, which accelerates the development of phenomena such as natural attenuation of contaminated sites. The objective of this study was to assess biodiversity of bacteria contained in anthropogenic contaminated soils $\left(\mathrm{H}_{\mathrm{S}}\right.$ and $\mathrm{H}_{\mathrm{p}}$ ) with PCBs compared to a control sample without contaminant and the modified forest (F) and agricultural (A) soil in the laboratory with $100 \mathrm{mg} \mathrm{L}^{-1}$ PCB. For the analysis of $16 \mathrm{~S}$ rRNA genes amplified from DNA extracted from the soils evaluated, the latest generation of Illumina Miseq and Sanger sequencing for the cultivable strains were detected. The bacteria identified as the most abundant bacterial phyla for $\mathrm{H}_{\mathrm{S}}$ and $\mathrm{H}_{\mathrm{p}}$ soil was Proteobacteria (56.7\%) and Firmicutes (22.9\%), which decreased in F and A soils. The most abundant bacterial genera were Burkholderia, Bacillus, Acinetobacter, Comamonas and Cupriavidus. Several species identified in this study, such as Bacillus cereus, Burkholderia cepacia, Comamonas testosteroni and Acinetobacter pittii have been reported as PCBs degraders. Finally, by means of a principal component analysis (PCA), a correlation between the physical and chemical characteristics of the soils in relation to the relative abundances of the bacteria identified was obtained. The $\mathrm{C} / \mathrm{N}$ ratio was directly related to the control soil (without contaminant), while SOM maintained a relationship with F and A soils and the bacterial abundances were directly related to $\mathrm{Hs}$ and $\mathrm{Hp}$ soils due to the presence of aroclor 1260 . Bacteria with the ability to tolerate high concentrations of this pollutant are considered for future use in biostimulation and bioaugmentation processes in contaminated soils.
\end{abstract}

Keywords: Bacterial diversity, Aroclor, Contaminated soils, Polychlorinated biphenyls

\footnotetext{
*Correspondence: reriro61@hotmail.com

${ }^{1}$ Tecnológico Nacional de México/IT de Tuxtla Gutiérrez, Carretera

Panamericana Km, 1080, CP 29050 Tuxtla Gutiérrez, Chiapas, Mexico

Full list of author information is available at the end of the article
}

\section{Key points}

- In this work, the bacterial communities of an anthropogenic site contaminated with polychlorinated biphenyls (PCBs) were analyzed in comparison with the communities detected in forest and agricultural soil evaluated in microcosms contaminated with PCBs. 
- A collection of bacterial strains with the ability to tolerate PCBs in culture media was obtained.

- The bacterial communities were related to the parameters $\mathrm{N}, \mathrm{C}$ and $\mathrm{P}$ of the soils that influence bacterial metabolic processes with the presence of PCBs and possibly in the mineralization of the contaminant".

\section{Introduction}

Polychlorinated biphenyls (PCBs) form a family of 209 congeners characterized by their chemical properties for use in industrial and commercial activities, such as electrical equipment (Furukawa and Fujihara 2008). PCBs are produced as complex mixtures that contained high variability of congeners and not as individual compounds. Each congener is structured by a biphenyl group to which they are attached between one and ten chlorine atoms, depending on the number of chlorine atoms (1-10) and their position (ortho, meta and para), PCB congeners differ in their physical and chemical properties (Passatore et al. 2014). Aroclor is the commercial name of a set of complex mixtures of PCBs (1242, 1254 and 1260) produced and sold in the US, which contains more than 100 PCB congeners. Aroclor is, therefore, the main source of accumulation of PCBs in America continent, including Mexico (Hu et al. 2011). PCBs mixtures are used mostly in the electrical industry, in equipment such as thermostats, condensers and in light transformers, where they constitute the main component ( $>70 \%$ ) of the oils used in this equipment as thermal insulators. These oils are called askareles and are composed of synthetic fluid, chlorobenzoates and PCBs (Hu and Hornbuckle 2010). However, they have high toxicity in humans with immunotoxin effects, tumorogenicity and carcinogenicity capabilities (Hayes et al. 1985; Silberhorn et al. 1990; Tryphonas et al. 1991) and other effects on different organisms (Sager and Girard 1994; Birnbaum 1995; Goldey et al. 1995). PCBs have been banned since 1970 (Matturro et al. 2016) however they are continuously released to the environment through spills, equipment leaks, improper disposal and storage, which represents a serious damage for ecosystems and human health (Nogales et al. 2011; Di Lenola et al. 2018). Therefore, most natural ecosystems and living organisms have been exposed to PCBs for several decades (Tehrani and Van 2014), so the elimination of PCBs accumulated in ecosystems have been an environmental problem at a global level, this challenge pursues the search for biological processes for their elimination (Robertson and Hansen 2015). Thus, these should include naturally occurring biodegradation processes together with added microbial communities able to survive in the presence of such toxic compounds (Matturro et al. 2015). Currently, the identity and role of microorganisms from sites affected by PCBs have been mainly from contaminated marine sediments (Pachiadaki et al. 2010; Pop et al. 2015; Dudášová et al. 2016) where several bacterial enrichments have been obtained and although they have been used matrices contaminated by PCBs, their role is not well documented (Nuzzo et al. 2017). Knowledge on the biodiversity of bacteria associated with sites contaminated by PCBs is still limited, particularly at sites other than marine sediments (Quero et al. 2015; Jugder et al. 2016). But there is ongoing research aimed at exploring the microbiome of sites contaminated with PCBs. Proteobacteria, Acidobacteria and Firmicutes are mainly reported as bacterial phyla associated with PCBs contaminated sediments (Hu et al. 2011; Nuzzo et al. 2017). Burkholderia, Comamonas, Cupriavidus, Pseudomonas, Rhodococcus and Paenibacillus, among others, have been reported as bacterial genera capable of eliminating certain congeners of PCBs (Qiu et al. 2015; Matturro et al. 2016; Horváthová et al. 2018). The aims of this study were investigate the diversity and abundance of bacteria in soils contaminated with polychlorinated biphenyls and correlate the characteristics of the soil and bacterial communities.

\section{Materials and methods \\ Experimental site description}

The experimental site named "La Herradura", was chosen for the high accumulation of askarels (PCBs congeners) used in electric transformers. This site is located in the municipality of Raudales Malpaso, Chiapas (Mexico) $\left(17.11^{\circ} \mathrm{N}, 93.36^{\circ} \mathrm{W}\right)$ at 136 masl, with an annual temperature above $35{ }^{\circ} \mathrm{C}$ and average yearly rainfall $\sim 309 \mathrm{~mm}$. The clay soil at the experimental site is classified as Albic Endostagnic Luvisol (Soil Survey Staff 2010).

\section{Sampling}

Askarel oil contaminated soil samples were collected from two sites. A one of them from the surface $(\mathrm{Hs})$ and another $50 \mathrm{~cm}$ depth $(\mathrm{Hp})$. Also, a control soil sample (not contaminated by askarel oil) was collected at a distance of $100 \mathrm{~m}$ from the Hs and Hp sites. Soil samples were grouped into three composed samples for each site $(n=3)$. Samples were transferred to sterile tubes of $50 \mathrm{~mL}$. All samples were kept at $8-10{ }^{\circ} \mathrm{C}$ during transport to laboratory. Samples used for metagenomic analysis were stored at $-80^{\circ} \mathrm{C}$ and those for isolating bacteria in cultures were processed as soon as possible. Additionally, soil samples were collected from a tropical forest and also from an agricultural crop (Additional file 1). Both samples were placed in microcosm and were each were subsequent contaminated with $100 \mathrm{mg} \mathrm{L}^{-1}$ askarel oil for 90 days (as a source of PCBs) to compare the effect 
of the pollutant on in the bacterial communities of these microcosms and correlate them with the control, $\mathrm{Hs}$ and Hp soils. The askarel used for samples F and A contained a mixture of aroclor 1242 and 1254 at a concentration of $30 \mathrm{mg} \mathrm{L}^{-1}$ and aroclor 1260 to $40 \mathrm{mg} \mathrm{L}^{-1}$ ). These soils were used as well in genomic and metagenomic studies (Matturro et al. 2016).

\section{Physicochemical analysis of soil}

The soils physicochemical properties collected at the $\mathrm{Hs}$ and $\mathrm{Hp}$ sites contaminated by PCBs (askarel) and of the control soil (uncontaminated) were determined. The $\mathrm{pH}$ and electric conductivity (EC) were measured using a digital pH meter Mettler Toledo ${ }^{\circledR}$ Model S220 (New York, USA) in 1:10 (weight/volume) aqueous solution. The soil organic matter (SOM) content, total carbon and $\mathrm{C}: \mathrm{N}$ ratio were analyzed according to AOAC methods (AOAC 1996). Total nitrogen was measured by Kjeldhal method (Bremner 1996). Total phosphorus was determined with the solubilization method of $\mathrm{HNO}_{3} / \mathrm{HClO}_{4}$. Also, the same determinations were done for forest (F) and agricultural (A) soil samples that were previously contaminated with askarel at $100 \mathrm{mg} \mathrm{L}^{-1}$.

\section{Polychlorinated biphenyl (PCB) quantification}

The concentration of polychlorinated biphenyl (PCB) in soil samples that were collected at the control, Hs and $\mathrm{Hp}$ sites and from the collected slurry in each microcosm contaminated by askarel oil was determined in terms of aroclor 1242, aroclor 1254 and aroclor 1260 as follows: The PCBs were extracted from $5 \mathrm{~g}$ of soil with $20 \mathrm{~mL}$ of pentane HPLC grade (Sigma-Aldrich, USA) and then mixed in vortex for $5 \mathrm{~min}$. Next, the supernatant was placed in a $15-\mathrm{mL}$ Falcon tube and the procedure was repeated twice. The pentane was then concentrated to $1.0 \mathrm{~mL}$ using a rotary evaporator. Analysis was performed by gas chromatography (GC) with electron capture detector (ECD) on a Trace GC equipped with a $30-\mathrm{m} \times 0.25-\mathrm{mm} \times 0.25-\mu \mathrm{m}$ HP5 capillary column (Agilent Technologies, Palo alto, CA, USA). The injector and transfer line temperatures were 250 and $300{ }^{\circ} \mathrm{C}$, respectively. The oven temperature was held at $60^{\circ} \mathrm{C}$ for $1 \mathrm{~min}$, then increased to $160{ }^{\circ} \mathrm{C}$ at a rate of $20^{\circ} \mathrm{C} \mathrm{min}{ }^{-1}$, further increased to $300{ }^{\circ} \mathrm{C}$ at a rate of $6{ }^{\circ} \mathrm{C} \mathrm{min}{ }^{-1}$, and held for $2 \mathrm{~min}$. helium was employed as the carrier gas with a constant flow of $1 \mathrm{~mL} \mathrm{~min}{ }^{-1}$. For quantitative analysis, the PCB calibration mixes in aroclor 1242, 1254 and 1260 (Sigma-Aldrich, USA) were used.

\section{DNA extraction and PCR amplification of bacterial 16S rRNA gene}

DNA was extracted from $1.5 \mathrm{~g}$ soil (three times from $0.5 \mathrm{~g})$ through the DNeasy Power Soil commercial kit.
DNA concentration was quantified on a Nano Drop 2000 spectrophotometer. Triplicate PCR reactions were done to amplify the V3-V4 16S rRNA gene hypervariable regions for each metagenomic DNA sample. PCR amplification were done using 8-pb barcoded primers 341-F (5'-CTACGGGGGCGCAG-3') and 805-R (5'-GACTAC GGGTATCTAATCC-3'). Pool PCR products were clean using FastGene columns (Nippon Genetics, Co., Ltd) and amplicon products quantification was done with Nanodrop and then sequencing was performed by Macrogen Inc. (DNA Sequencing Service, Seoul, Korea) using Illumina Miseq $2 \times 300$ paired-end (Ceja-Navarro et al. 2010).

\section{Analysis of genetic sequences}

The QIIME version 2.0 software pipeline was used to analyze the sequencing data (Caporaso et al. 2010a). The poor quality readings were eliminated from the data sets, i.e. quality score $<25$, containing homopolymers $>6$, length $<400 \mathrm{nt}$, and containing errors in primers and barcodes. Operational taxonomic units (OTUs) were determined at $97 \%$ similarity level with UCLUST algorithm (Edgar 2010). Chimeras were detected and removed from the data sets using the Chimera Slayer (Haas et al. 2011). Sequence alignments were done against the Greengenes core set and using representative sequences of each OTU using PyNAST, and filtered at a threshold of $75 \%$ (Caporaso et al. 2010b). Taxonomic assignation was done with rarified data sets at 850 reads per sample to compare the same amount of sequences and using the naïve Bayesian rRNA classifier from the Ribosomal Data Project (http://rdp.cme.msu.edu/classifier/classifier.jsp) at a confidence threshold of $80 \%$ (Wang et al. 2007). The illumina sequencing data reported herein was registered in the NCBI as a BioProject (ID: PRJNA622403) and deposited as a Sequence Read Archive (SRA) database under accession numbers of SAMN14514156 to SAMN14514160.

\section{Bacterial isolation and DNA extraction}

Five $\mathrm{g}$ of each soil was placed in modified minimum medium $\left(8.1 \%\left(\mathrm{NH}_{4}\right)_{2} \mathrm{SO}_{4}, 16.31 \% \mathrm{~K}_{2} \mathrm{HPO}_{4}, 4.91 \% \mathrm{NaCl}\right.$ and $\mathrm{MgSO}_{4} \cdot 7 \mathrm{H}_{2} \mathrm{O}$ 49.18\% dextrose anhydride, $16.11 \%$ yeast extract and $0.49 \% \mathrm{FeSO}_{4} \cdot 7 \mathrm{H}_{2} \mathrm{O}$ ) added with $250 \mathrm{mg}$ $\mathrm{L}^{-1}$ of biphenyl. For this initial process, soils were placed in $25 \mathrm{~mL}$ broth obtaining a base solution. Then serial dilutions $10^{-1}$ to $10^{-6}$ were done and $10 \mu \mathrm{L}$ of each bacterial dilution was streaked on the minimum medium previously mentioned. Plates were incubated at $30{ }^{\circ} \mathrm{C}$ for 5 days. Pure cultures were preserved in $65 \%$ glycerolminimum medium broth at $4{ }^{\circ} \mathrm{C}$. Total genomic DNA of each strain was extracted using the DNA Isolation Kit Fungal/Bacterial (Zymo Research) according to the manufacturer specifications. Extracted genomic DNA 
was verified by $1 \%$ agarose gel electrophoresis and with Nanodrop'.

\section{S rDNA gene, genetic fingerprinting and phylogenetic analysis of the isolates}

To generate DNA genetic patterns BOX_A1R oligo was used, as described by Koeuth et al. (1995). The genomic patterns were identified through electrophoresis in 1.5\% agarose gels. The Shannon-Weaver index of richness (d) and diversity $(\mathrm{H})$ were calculated based on BOX_PCR genetic profiles. The PCR of the $16 \mathrm{~S}$ rDNA gene was performed with the universal primers for bacteria $\mathrm{AD} 1\left(5^{\prime}\right.$ AGAGTTTGATCCTGGCTCAG-3') and rD1 (5'-AAG GAGGTGATCCAGCC-3') (Weisburg et al. 1991) using an Applied Biosystems model 2720 thermocycler (Ca, USA). PCR conditions consisted of an initial denaturing step at $94{ }^{\circ} \mathrm{C}$ for $5 \mathrm{~min}, 35$ cycles $\left(94{ }^{\circ} \mathrm{C}\right.$ for $1 \mathrm{~min}, 55^{\circ} \mathrm{C}$ for $1 \mathrm{~min}$ and $72{ }^{\circ} \mathrm{C}$ for $2 \mathrm{~min}$ ) and an additional final chain elongation step at $72{ }^{\circ} \mathrm{C}$ for $7 \mathrm{~min}$. The size of the amplification products was verified by electrophoresis in $1 \%$ agarose gels. PCR products were purified using the PCR product purification system kit (Roche TM, Switzerland). The PCR-16S rDNA products were digested with the RsaI restriction enzyme (Thermo Scientific) using the Amplified rDNA Restriction Analysis (ARDRA) and were observed through electrophoresis in 3\% agarose gel, to use them in diversity analysis. The amplification mixture was purified using the Roche PCR product purification system, before sequencing. The PCR products sequenced (Macrogen), were compared using BLAST and analysis tools of Ribosomal Database Project-II (Altschul et al. 1990). The taxonomically related sequences obtained from the National Center for Biotechnology Information (NCBI) were aligned by the CLUSTAL X (2.0) software with default settings (Larkin et al. 2007). Phylogenetic and molecular evolutionary analysis were performed with MEGA v5.2 (Tamura et al. 2011).

\section{Nucleotide sequence accession numbers}

The sequences of strain reported herein were deposited in the GenBank with the accession numbers from MH921878, MH921879, MH921881, MH921883, MH921884, MH921887 and MH921888 for strains isolated from control soil. For the isolates obtained from the Hs site, the range of numbers were from MH209072 to MH209076. The range of numbers for the Hp site were from MH921875 to MH921877. The sequences for the isolates of forest soil (F) contaminated with PCBs were registered with the numbers MN685207, MN685208, MN685209, MN818571 and MN818574, and those isolated from the agricultural soil (A), the numbers were MN685210, MN685211, MN685212, MN818572 and MN818573.
In the case of the bacterial strains (Table 4), these were deposited in the collection of microbial strains of the 'Centro de Ciencias Genomicas' CCG-UNAM (Mexico).

\section{Statistical analysis}

Physicochemical variables of soils and concentration of PCBs (as aroclor congeners mixtures) were evaluated by one-way analysis of variance (ANOVA). Mean difference significance was tested with the Tukey test and also by the $t_{-}$student's statistics $(p<0.05)$. The correlation between relative abundance of the bacterial groups at phyla taxonomic level and each type of soil, and the relation of the abundance with physicochemical characteristics were explored with a principal component analysis (PCA). Minitab 18.1 was used for statistics analyses (2017 Minitab, Inc. All rights reserved).

\section{Results \\ Soil characteristics}

The physicochemical analysis allowed to determine that there are significant variations between the different parameters evaluated in anthropogenic soils contaminated with PCBs compared to agricultural (A) and forest (F) soils that were enriched with the pollutant askarel (Table 1). In the case of $\mathrm{pH}$, this proved to be more acidic in soils collected at sites Hs and Hp, where there was a high concentration of PCBs, while in forest soils and in agricultural soils, the $\mathrm{pH}$ was slightly alkaline. In the case of electric conductivity (EC) did not show significant difference in any of the samples evaluated. The apparent density was different among the treatments evaluated (soils), being lower in those soils that presented anthropogenic contamination by askarels. With respect to the parameters related to soil fertility (SOM, total carbon, total nitrogen and total phosphorus) showed significant differences $(p<0.05)$ between the treatments evaluated. The soil organic matter (SOM) content was significantly higher in soils of agricultural nature contaminated with PCB compared to the rest of the treatments. Also, the total carbon, total nitrogen and total phosphorus content was higher in this type of soil. The $\mathrm{C}: \mathrm{N}$ ratio is a parameter that indicates the functionality of the soils. In our case, control soil samples (without PCBs) had a higher $\mathrm{C}: \mathrm{N}$ ratio compared to $\mathrm{PCB}$ contaminated soils.

The content of PCBs in terms of mixtures of aroclors 1242, 1254 and 1260 was determined in polluted soils collected at sites Hs, Hp, F and A (Table 2). Gas chromatography allowed to determine that the concentration of the mixture of aroclor 1242 was higher in the soils obtained from the Hs site $\left(30.72 \mathrm{mg} \mathrm{kg}^{-1}\right)$ and in the case of the mixture of aroclor 1254 it was detected in a lower concentration $\left(<10.54 \mathrm{mg} \mathrm{kg}^{-1}\right)$, however, a higher concentration of this contaminant $\left(>60 \mathrm{mg} \mathrm{kg}^{-1}\right)$ was 
Table 1 Characteristics of soil contaminated PCBs

\begin{tabular}{|c|c|c|c|c|c|c|c|c|c|}
\hline Sample & $\begin{array}{l}\text { Soil } \\
\text { classification } \\
\text { (texture) }^{a}\end{array}$ & $\mathrm{pH}$ & $\mathrm{EC}\left(\mathrm{dS} \mathrm{m^{-1 } )}\right.$ & $\begin{array}{l}\text { Density } \\
\left(\mathrm{g} \mathrm{mL}^{-1}\right)\end{array}$ & SOM (\%) & Total P (mg/kg) & Total C (mg/kg) & Total N (mg/kg) & C:N ratio \\
\hline Control & \multirow[t]{3}{*}{ Luvisol (clayey) } & $5.5 \mathrm{E}^{\mathrm{b}}$ & $0.063 \mathrm{~A}$ & $1.17 \mathrm{~B}$ & $14.17 C$ & $5.65 C$ & $7.26 \mathrm{BC}$ & $0.53 C$ & $13.70 \mathrm{~A}$ \\
\hline $\mathrm{H}_{\mathrm{S}}$ & & $5.8 \mathrm{C}$ & $0.047 \mathrm{~A}$ & $1.0 \mathrm{D}$ & $10.73 \mathrm{D}$ & $4.85 \mathrm{D}$ & $6.40 \mathrm{CD}$ & $0.48 \mathrm{D}$ & $11.75 B$ \\
\hline$H_{p}$ & & $5.6 \mathrm{D}$ & $0.063 \mathrm{~A}$ & $1.08 \mathrm{C}$ & $9.04 \mathrm{E}$ & $6.06 \mathrm{~B}$ & $4.84 \mathrm{D}$ & $0.49 \mathrm{D}$ & $9.81 \mathrm{D}$ \\
\hline$F$ & \multirow{4}{*}{$\begin{array}{l}\text { Regosol (silty- } \\
\text { loam) }\end{array}$} & $7.0 \mathrm{~B}$ & $0.076 \mathrm{~A}$ & $1.25 \mathrm{~A}$ & $20.11 B$ & $3.48 \mathrm{E}$ & $9.05 \mathrm{AB}$ & $0.91 \mathrm{~B}$ & $9.87 \mathrm{D}$ \\
\hline$A$ & & $7.8 \mathrm{~A}$ & $0.055 \mathrm{~A}$ & $1.15 B$ & $21.46 \mathrm{~A}$ & $10.44 \mathrm{~A}$ & $10.65 \mathrm{~A}$ & $0.96 \mathrm{~A}$ & $11.09 \mathrm{C}$ \\
\hline \multirow{2}{*}{$\begin{array}{l}p \text {-value } \\
\text { HSD } \\
(p<0.05)\end{array}$} & & 0.0000 & 0.6824 & 0.0000 & 0.0000 & 0.0000 & 0.0000 & 0.0000 & 0.0000 \\
\hline & & 0.0404 & 0.0663 & 0.0416 & 0.1953 & 0.0628 & 1.7888 & 0.0360 & 0.6158 \\
\hline
\end{tabular}

EC electric conductivity, SOM soil organic matter, C:N carbon:nitrogen ratio, HSD honest significant difference (Tukey's test)

a According to Soil Survey Staff (2010)

b The means followed by the same capital letter do not show any significant differences (Tukey's test, $p<0.05$ )

Table 2 Quantification of polychlorinated biphenyls (PCBs) as aroclor mixture in soil sample

\begin{tabular}{lllll}
\hline Sample & \multicolumn{4}{l}{ Aroclor $\left(\mathbf{m g ~ k g}^{\mathbf{- 1}}\right)$} \\
\cline { 2 - 5 } & $\mathbf{1 2 4 2}$ & $\mathbf{1 2 5 4}$ & $\mathbf{1 2 6 0}$ & Total mixture \\
\hline Control & $\mathrm{ND}$ & $\mathrm{ND}$ & $\mathrm{ND}$ & $\mathrm{ND}$ \\
$\mathrm{H}_{\mathrm{S}}$ & $30.72 \pm 2.6$ & $10.54 \pm 1.6$ & $60.72 \pm 6.2$ & $101.98 \pm 10.4$ \\
$\mathrm{H}_{\mathrm{P}}$ & $25.45 \pm 3.2$ & $8.75 \pm 1.2$ & $88.19 \pm 7.6$ & $122.39 \pm 12.0$ \\
$\mathrm{~F}$ & $30.0 \pm 0.1$ & $30.0 \pm 0.1$ & $40.0 \pm 0.1$ & $100.0 \pm 0.1$ \\
$\mathrm{~A}$ & $30.0 \pm 0.1$ & $30.0 \pm 0.1$ & $40.0 \pm 0.1$ & $100.0 \pm 0.1$ \\
\hline
\end{tabular}

$N D$ not detected

recorded in the aroclor 1260 mixture. On the other hand, the total sum of the concentrations of the three mixtures of aroclor $(1242,1254$ and 1260) was higher at the Hp site $\left(122.39 \mathrm{mg} \mathrm{kg}^{-1}\right)$ compared to the aroclor concentration determined at the Hs site $\left(101.98 \mathrm{mg} \mathrm{kg}^{-1}\right)$. These concentrations of PCBs were detected in the samples are above the permitted values according to the
NOM-133-SEMARNAT-2015 standard for soils contaminated by PCBs in Mexico. In the case of soil samples $\mathrm{F}$ and $\mathrm{A}$, a concentration of $100 \mathrm{mg} \mathrm{kg}^{-1}$ of the aroclor mixture was detected.

\section{Bacterial communities structure in the soils}

A total of 14,500 sequences were obtained of all the soil samples with the observed OTUs (Operational Taxonomic Units) ranging from 1751 to 4489 for the five soils evaluated.

Richness and diversity of bacterial species were estimated in the different soil samples using cultivable and non-cultivable methods showing significant variations (Table 3). In the non-cultivable method, both the Chao index as well as the ACE showed a high abundance $(d)$ of bacterial species in the $\mathrm{Hp}$ soil that were contaminated with PCBs (aroclor mixture). Likewise, the diversity $(H)$ of species were greater in the $\mathrm{Hp}$ soil according to the Shannon and Simpson index. In contrast to the cultivable method, the Shannon-Weaver index estimated a high abundance $(H=4.7)$ and diversity $(d=1.3)$ of species in

Table 3 Richness and diversity of bacterial communities in soils contaminated PCBs

\begin{tabular}{|c|c|c|c|c|c|c|c|}
\hline \multirow[t]{4}{*}{ Sample } & \multirow[t]{4}{*}{ OTUs } & \multicolumn{6}{|l|}{ Index } \\
\hline & & \multicolumn{4}{|c|}{ Non-cultivable method } & \multicolumn{2}{|l|}{ Cultivable method } \\
\hline & & \multicolumn{2}{|c|}{ Richness $(d)$} & \multicolumn{2}{|c|}{ Diversity $(H)$} & \multirow{2}{*}{$\begin{array}{l}\text { Richness }(d) \\
\text { Shannon-Weaver }\end{array}$} & \multirow[t]{2}{*}{ Diversity $(H$} \\
\hline & & Chao 1 & ACE & Shannon & Simpson & & \\
\hline Control & 3345 & 6252.3 & 7076.8 & 9.3 & 1.0 & 4.7 & 1.3 \\
\hline $\mathrm{H}_{\mathrm{s}}$ & 3063 & 6013.7 & 6551 & 8.6 & 1.0 & 4.1 & 1.1 \\
\hline$H_{p}$ & 4489 & 9425.7 & $10,474.1$ & 10 & 1.1 & 3.2 & 0.9 \\
\hline$F$ & 1751 & 1979 & 2117.4 & 7.8 & 0.9 & 3.4 & 1.0 \\
\hline$A$ & 1852 & 2261.4 & 2492.1 & 7.5 & 0.9 & 3.3 & 1.0 \\
\hline
\end{tabular}

ACE abundance-based coverage estimator

OTU: Operational taxonomic units as determined by Uclust (Edgar 2010) at a similarity threshold of $97 \%$ 
the control soil (without contaminant). Both the abundance and diversity of species are decreasing as soils have been contaminated by PCBs.

The identification of bacterial phyla was over $90 \%$, in the different soils evaluated (Fig. 1). Phylotypes belonged to 9 different phyla, which contributed $>1 \%$ of the sequences. The control sample (without PCBs) showed Acidobacteria (46.4\%), Proteobacteria (33.7\%), Verrucomicrobia (4.3\%), Actinobacteria (2.7\%) and Firmicutes (2.5\%). The soil Hs sample contaminated with PCBs (aroclor mixture) showed a greater abundance of Proteobacteria (56.7\%), Firmicutes (10.5\%), Actinobacteria (3.0\%) and Verrucomicrobia (6.6\%), but a marked decrease of Acidobacteria (13.4\%). In the case of the sample $\mathrm{H}_{\mathrm{p}}$ also showed an increase of Proteobacteria (23.0\%), Acidobacteria (16.0\%), Firmicutes (23.0\%), Actinobacteria (7.4\%) and Verrucomicrobia (3.3\%).

With respect to the soil samples obtained from $\mathrm{F}$ and A site, previously contaminated in vitro with PCBs (aroclor mixture) showed significant variations in relation to the relative sequence abundances at the phyla level. In sample F the relative abundance of the phyla Actinobacteria and Proteobacteria increased significantly (24.6 and
43.7\%, respectively), but showed a decrease in Acidobacteria (4.2\%). Sample A showed an increase in Proteobacteria (86.0\%) and Firmicutes (5.6\%), but had a decrease in relative abundance in Acidobacteria (4.9\%).

The bacterial composition of the control, Hs, Hp, F and A soils was studied at the genera level (Fig. 2). Fifty bacterial genera were identified. In the control sample (without contaminant), Candidatus solibacter belonging to the Acidobacteria phylum was the main genus found with a relative abundance $>5 \%$. Also, bacteria belonging to the genera Burkholderia, Bacillus, Clostridium, DA101, Rhodoplanes and Mycobacterium with a relative abundance $>1 \%$ were detected. In the case of the Hs sample (collected from PCB contaminated soil), Burkholderia belonging to Betaproteobacteria phylum was the most abundant bacterial genus $>18 \%$. Also, DA101 was among the main phylotypes found in this soil with a relative abundance $>5 \%$. In contrast, the Bacillus, Candidatus koribacter, Rhodoplanes and Clostridium genera showed a low abundance $>1.0 \%$. In the soil sample collected at the Hp site, the genera Bacillus, Candidatus, Clostridium and Nevskia were identified with a relative abundance higher than 6.0\%. Burkholderia, DA101, Bradyrhizobium

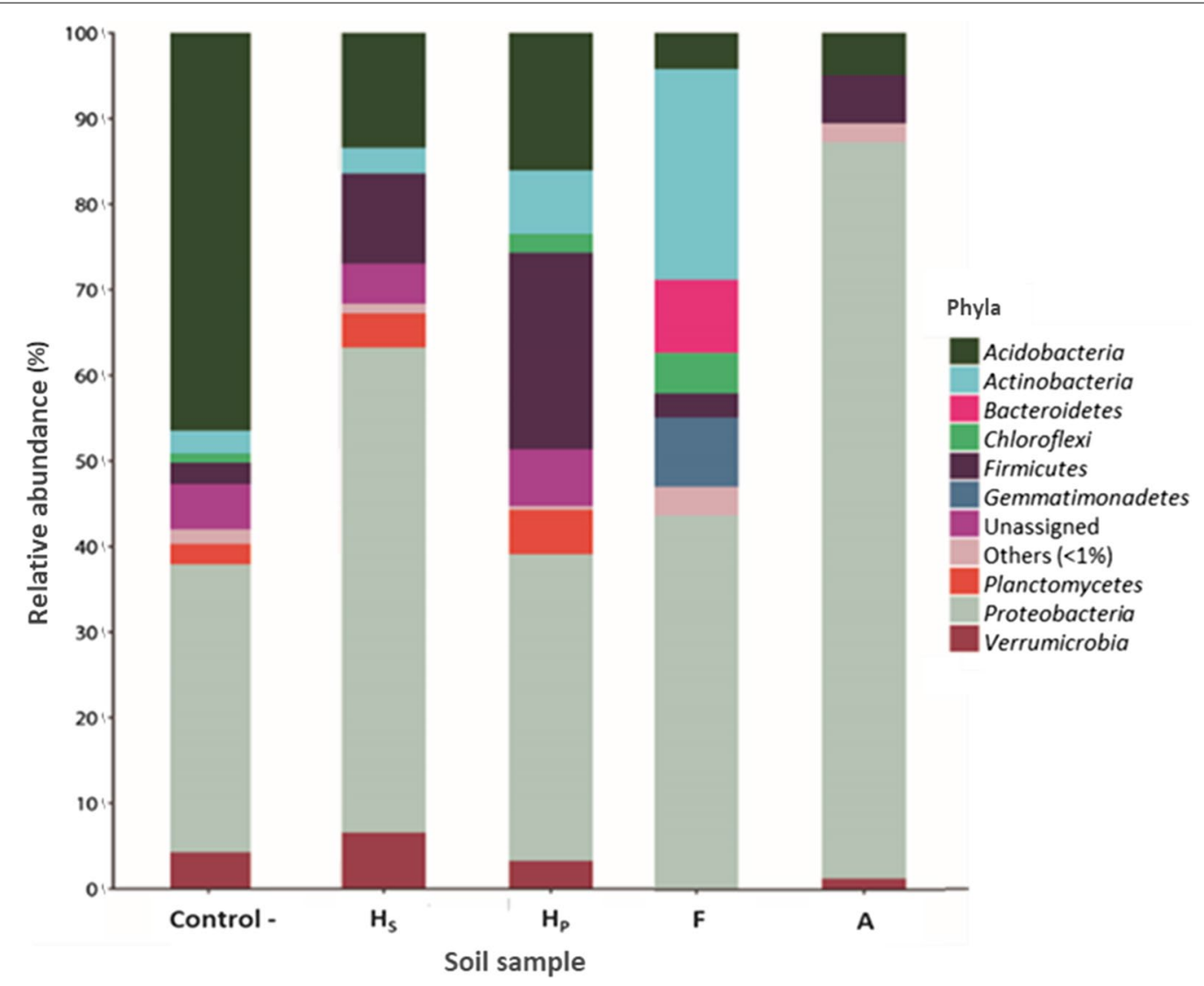

Fig. 1 Bar plot with relative abundance of the different bacterial phyla found in soils contaminated PCBs 


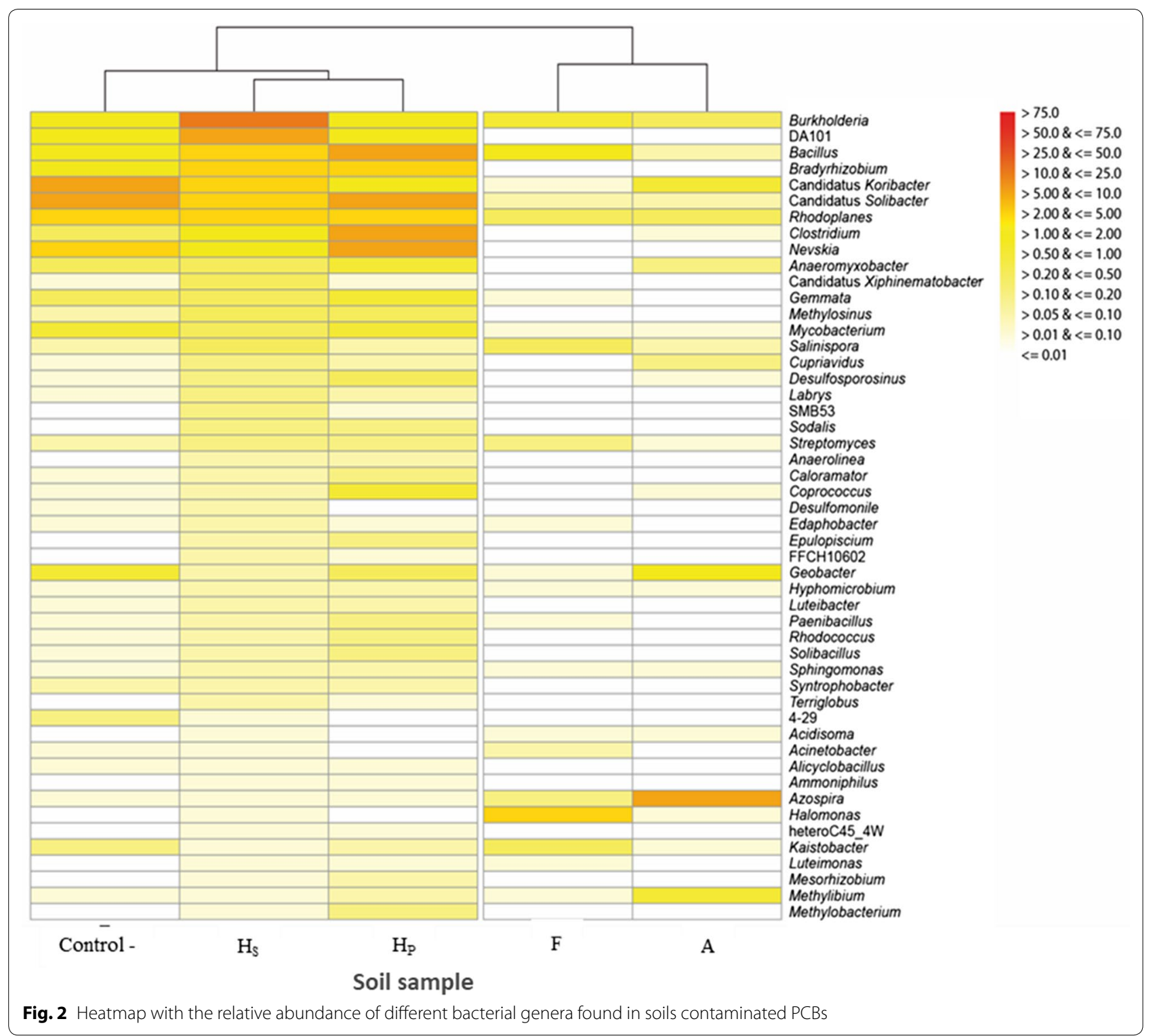

and Rhodoplanes with a relative abundance $>1.0 \%$ were also the bacterial genera found in this type of soil contaminated by PCBs (aroclor mixture).

With respect to $\mathrm{F}$ and $\mathrm{A}$ samples that were previously contaminated in vitro with a mixture of aroclor, these showed significant variations in relation to the relative abundance of the bacterial genera identified in these soils. The bacterial genera Burkholderia, Bacillus, Halomonas, Kaistobacter, Rhodoplanes, and Streptomyces were identified in sample $\mathrm{F}$ with abundance above $1 \%$. While the genus Azospira with an abundance $>8.0 \%$, as well as the genera Burkholderia, Rhodoplanes and Cupriavidus with an abundance $>1.0 \%$ were identified as bacterial components in soil sample A.
A phylogenetic analysis based on the $16 \mathrm{~S}$ rRNA gene sequences of cultivable bacterial strains isolated from different PCB-contaminated soils was performed. A total of 135 bacterial strains were obtained from different soil sampling sites (Control, $\mathrm{H}_{\mathrm{S}}, \mathrm{H}_{\mathrm{P}}, \mathrm{F}$ and $\mathrm{A}$ ). Thus, of the 135 strains isolated, 25 different ARDRA genomic profiles were obtained (Table 4). Of which seven morphotypes corresponded to the control soil, five were from the soil sample Hs, three from the sample Hp. Also five ARDRA profiles were of samples obtained from forest soil and five corresponded to agricultural soils. The Shannon-Weaver index showed a higher diversity $(H=1.3)$ and richness $(d=4.7)$ of bacterial species isolated from the control sample, in 
Table 4 Taxonomic affiliation of the bacteria isolated of soils contaminated PCBs

\begin{tabular}{|c|c|c|c|c|c|}
\hline \multirow[t]{2}{*}{ Sample site } & \multirow{2}{*}{$\begin{array}{l}\text { ARDRA } \\
\text { profiles }^{\text {a }}\end{array}$} & \multicolumn{3}{|c|}{ Phylogenetic relationship } & \multirow[t]{2}{*}{ Phylum } \\
\hline & & $\begin{array}{l}\text { Representative } \\
\text { isolate }\end{array}$ & Closest NCBI match/similarity (\%) ${ }^{\mathbf{b}}$ & Accession number & \\
\hline \multirow[t]{7}{*}{ Control soil } & A-A & DCB13 & Bacillus thuringiensis L2.TYA/95.6 & MH921878 & Firmicutes \\
\hline & $A-B$ & DCB14 & Bacillus cereus H3/96.4 & MH921879 & Firmicutes \\
\hline & $A-C$ & DCB18 & Bacillus paramycoides SBMS4/95.7 & MH921881 & Firmicutes \\
\hline & $A-D$ & DCB20 & Achromobacter denitrificans DBT224/98.9 & MH921883 & Proteobacteria \\
\hline & $A-E$ & DCB21 & Bacillus paranthracis J-131/98.8 & MH921884 & Firmicutes \\
\hline & $A-F$ & DCB26 & Cupriavidus malaysiensis USMAA1020/99.2 & MH921887 & Proteobacteria \\
\hline & $A-G$ & DCB27 & Bacillus cereus XS 2-8/97.7 & MH921888 & Proteobacteria \\
\hline \multirow[t]{5}{*}{$\mathrm{Hs}$} & B-A & DCB01 & Burkholderia cenocepacia Z6/96.0 & MH209072 & Proteobacteria \\
\hline & B-B & DCB02 & Burkholderia ambifaria ChDC B361/95.2 & MH209073 & Proteobacteria \\
\hline & $\mathrm{B}-\mathrm{C}$ & DCB03 & Burkholderia cepacia BC16/95.3 & MH209074 & Proteobacteria \\
\hline & $B-D$ & DCB04 & Myroides odoratus (LT899994.1)/96.6 & MH209075 & Flavobacteriia \\
\hline & B-E & DCB05 & Bacillus cereus PR12/97.0 & MH209076 & Firmicutes \\
\hline \multirow[t]{3}{*}{$\mathrm{Hp}$} & C-A & DCB07 & Burkholderia anthina MYSP113/97.0 & MH921875 & Proteobacteria \\
\hline & $C-B$ & DCB08 & Burkholderia vietnamiensis BU97/95.0 & MH921876 & Proteobacteria \\
\hline & $\mathrm{C}-\mathrm{C}$ & DCB12 & Bacillus anthracis A4/98.3 & MH921877 & Firmicutes \\
\hline \multirow[t]{5}{*}{$\mathrm{F}$} & D-A & DCB101 & Acinetobacter pittii AB17H194/99.0 & MN685207 & Proteobacteria \\
\hline & D-B & DCB102 & Kosakonia arachidis LGR-9/99.5 & MN685208 & Proteobacteria \\
\hline & $\mathrm{D}-\mathrm{C}$ & DCB103 & Comamonas testosteroni OTU-c14/98.1 & MN685209 & Proteobacteria \\
\hline & D-D & DCB120 & Enterobacter ludwigii 7D2C3/99.7 & MN818571 & Proteobacteria \\
\hline & D-E & DCB124 & Staphylococcus saprophyticus SPB40-5/99.4 & MN818574 & Firmicutes \\
\hline \multirow[t]{5}{*}{ A } & E-A & DCB104 & Acinetobacter baumannii B8342/99.0 & MN685210 & Proteobacteria \\
\hline & $\mathrm{E}-\mathrm{B}$ & DCB105 & Burkholderia cenocepacia Z6/97.6 & MN685211 & Proteobacteria \\
\hline & $\mathrm{E}-\mathrm{C}$ & DCB106 & Comamonas testosteroni F4/98.6 & MN685212 & Proteobacteria \\
\hline & $E-D$ & DCB122 & Enterobacter oryzae Ola 01/98.1 & MN818572 & Proteobacteria \\
\hline & $E-E$ & DCB123 & Comamonas testosteroni 22/99.9 & MN818573 & Proteobacteria \\
\hline
\end{tabular}

a Representative isolate selected by ARDRA profile

b Similarity percentage was estimated by considering the number of nucleotide-substitutions between a pair of sequences divided by the total number of compared bases $\times 100 \%$

contrast to the diversity of bacterial species in soils contaminated with PCBs (aroclor), which decreases significantly.

The isolates were taxonomically classified within the phyla Proteobacteria, Firmicutes and Flavobacteria (Table 4). In detail, the bacterial genera Achromobacter, Bacillus and Cupriavidus were identified from the control sample (A-ARDRA group). For the $\mathrm{H}_{\mathrm{S}}$ sample (B-ARDRA group), the genera Burkholderia, Bacillus and Myroides were the most abundant. In the case of $\mathrm{H}_{\mathrm{P}}$ sample (C-ARDRA group), Burkholderia and Bacillus were the genera grouped. Acinetobacter, Comamonas, Enterobacter, Kosakonia and Staphylococcus were identified in F sample (D-ARDRA group). Finally, the isolates obtained the A sample (E-ARDRA group) were grouped within the genera Acinetobacter, Burkholderia, Comamonas and Enterobacter.

\section{Principal component analysis (PCA)}

The PCA considered the relative abundances of the different bacterial phyla and the separated $\left(\mathrm{H}_{\mathrm{S}}\right.$ and $\mathrm{H}_{\mathrm{P}}$ ) anthropogenic samples contaminated with PCBs and their control (without $\mathrm{PCB}$ ) from the comparative samples of forest (F) and agricultural (A) (Fig. 3). The total soil samples evaluated were characterized by a positive PC1, where the bacterial phyla with the greatest relative abundance were Actinobacteria, Firmicutes, Verrucomicrobia and Plantomycetes, which are considered oligotrophic organisms. While the bacterial phyla Gemmatimonadetes and Chloroflexi presented negative $\mathrm{PC} 1$ and were characterized by greater relative abundance. The samples of $\mathrm{F}, \mathrm{A}$ and $\mathrm{H}_{\mathrm{S}}$ soils were characterized by a positive $\mathrm{PC} 2$ related to the group of phyla Actinobacteria, Gemmatimonadetes and Cloroflexi, which have been related in processes 


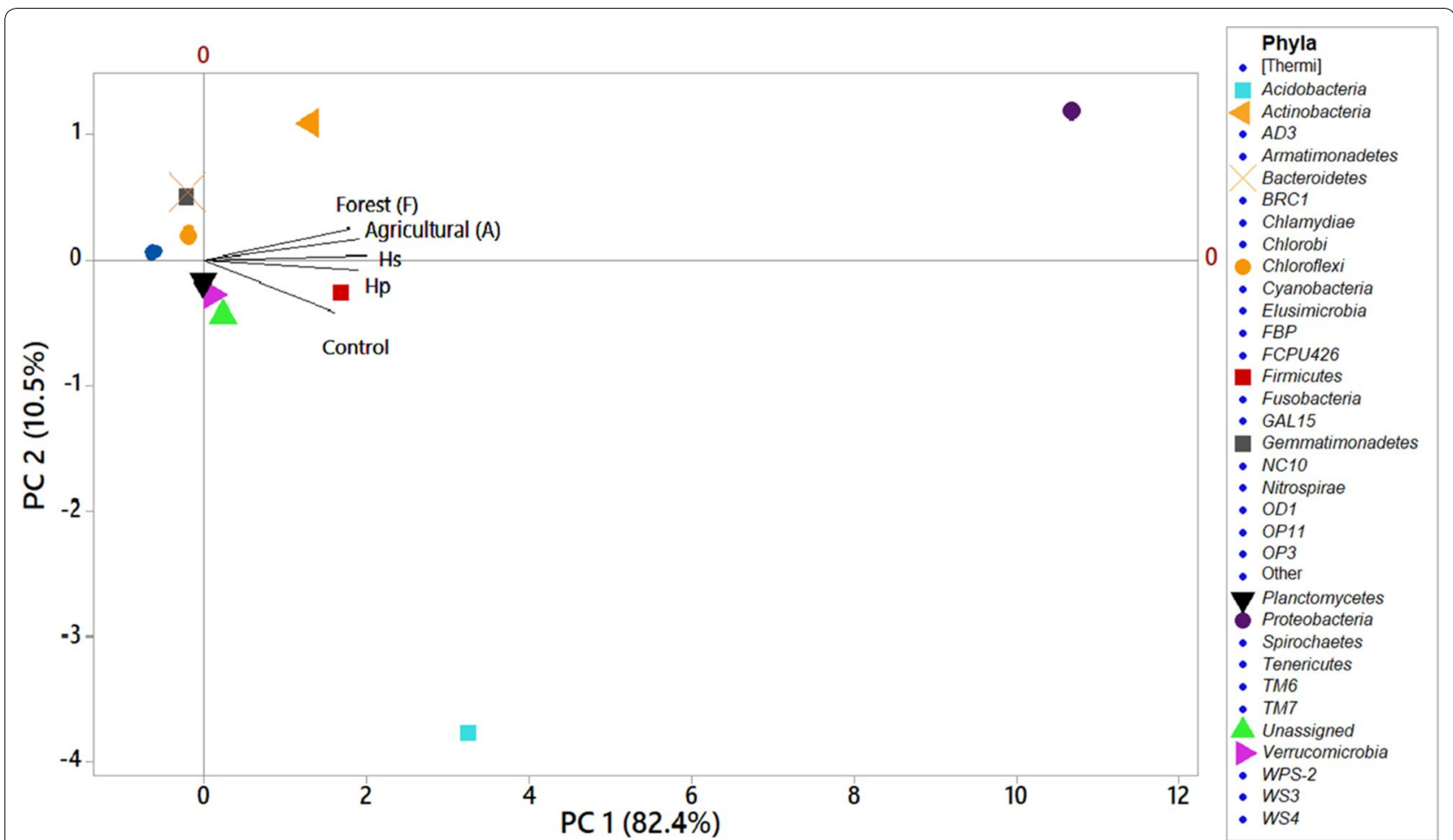

Fig. 3 The principal component analysis separated the relative abundances of the different bacterial phyla found in the sites contaminated by PCBs, both anthropogenic and comparative control, in relation to the types of soil evaluated (Control, $\mathrm{H}_{\mathrm{s}}, \mathrm{H}_{\mathrm{p}}, \mathrm{F}$ and $\mathrm{A}$ ). The main component (PC) 1 varies $82.4 \%$ of the variation and (PC) 2 (10.5\%)

of remediation of contaminants, while the phyla Firmicutes, Verrucomicrobia and Plantomycetes were related to $\mathrm{H}_{\mathrm{P}}$ and control soils by a negative PC2. The rest of the evaluated phyla were located at the same point within the PCA, located with a negative PC1 and positive $\mathrm{PC} 2$, but their relative abundance was relatively small for their separation. Another PCA related the specific abundances of bacterial phylum with the physicochemical characteristics of the soil and the PCBs concentrations in aroclor mixtures quantified in the different samples (Fig. 4). F and A samples were characterized by a positive PC1 in counterpart with the control. $\mathrm{H}_{\mathrm{S}}$ and $\mathrm{H}_{\mathrm{P}}$ samples that were characterized by a negative PC1.

With regard to physicochemical characteristics, $\mathrm{pH}$, $\mathrm{EC}$, density, total $\mathrm{C}$, total $\mathrm{P}$ and SOM were characterized by a positive $\mathrm{PC} 1$, while total $\mathrm{N}$ was the only property that had a negative PC1. With respect to the concentrations of PCBs, mixtures of aroclor 1242 and 1254 had a positive PC1 in counterpart with the mixture of aroclor 1260 which presented a negative PC1. The EC, density, total $\mathrm{C}$ and SOM properties were characterized by a positive $\mathrm{PC} 2$, in contrast to the $\mathrm{pH}$, Total $\mathrm{P}$, total $\mathrm{N}$ and the three mixtures of aroclor that had a negative PC2.

\section{Discussion}

The polychlorinated biphenyls (PCBs) contamination in ecosystems and terrestrial biomes around the world continues to worry to scientists, considering the high degree of toxicity of this compound. For this reason, the search and selection of native microorganisms with potential of the removal and degradation of PCBs is increasing significantly. In this study, the structure and diversity of native bacterial communities in soils contaminated with PCBs were evaluated. The physical-chemical analysis of the soils collected at contaminated sites ( $\mathrm{Hs}, \mathrm{Hp}, \mathrm{F}$ and A) and the control sample (uncontaminated) was evaluated, while the data analysis allowed to determine significant differences between the sampling sites (treatments) in relation to the studied parameters (Table 1). For instance, the soil $\mathrm{pH}$ was more acidic in the control samples and also in those contaminated samples ( $\mathrm{Hs}$ and $\mathrm{Hp}$ ) compared to the $\mathrm{F}$ and $\mathrm{A}$ samples, which had a neutral $\mathrm{pH}$ (7.0 to 7.8). There is no clear information that PCBs has an effect on soil $\mathrm{pH}$. The $\mathrm{pH}$ variations recorded in the soils can be attributed to the geological nature of the soil. That is, the control, Hs and Hp soils were classified as luvisol (Soil Survey Staff 2010). These soils are clay and slightly acidic, with an adequate content of organic matter and a high content of aluminum and iron. In the case 


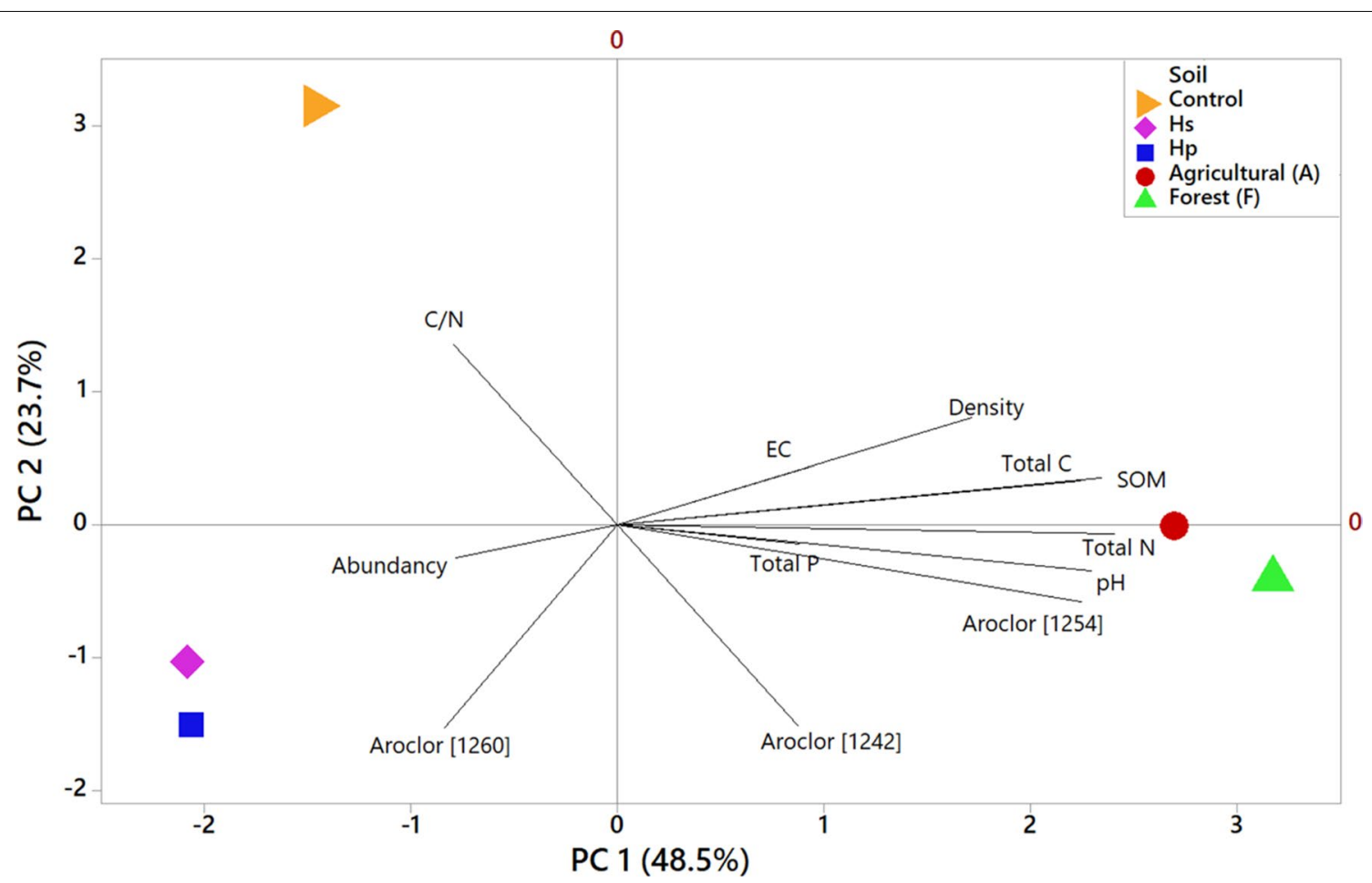

Fig. 4 Principal component analysis considering the relative abundance of the different bacterial phyla, soil characteristics and levels of PCBs contamination. Principal component (PC 1) explained $48.5 \%$ of the variation and PC 2 (23.7\%)

of $\mathrm{F}$ and A soils, these were of the regosol type, which are slightly alkaline, with a high content of organic matter and rich in calcium and magnesium. Likewise, no discernable differences between the different samples were determined in related to electrical conductivity (EC). It is known that the $\mathrm{EC}$ is related to the salinity content of the soil (Zenteno-Rojas et al. 2019). The samples obtained in soil $\mathrm{F}$ had the highest EC value $\left(0.076 \mathrm{dS} \mathrm{m}^{-1}\right)$, this could be due to the high content of $\mathrm{Ca}^{2+}$ and $\mathrm{Mg}^{2+}$ ions that is common in soils obtained from tropical forests (regosols). The apparent density varied significantly $(p<0.05)$ among the analyzed soils. In soil sample $\mathrm{F}$ a high density was recorded, indicating that it is a highly compacted soil. Both characteristics influence the density and waterholding capacity, which facilitates the accumulation of other substances, such as askarel oils in this type of soil (Horváthová et al. 2018).

In $\mathrm{F}$ and $\mathrm{A}$ soils a high content of soil organic matter (SOM) was found compared to the control, $\mathrm{Hs}$ and Hp soils (Table 1). This is important, considering that organic matter and PCBs are the main source of carbon that will be used by bacterial communities to carry out the biochemical processes of mineralization of these organic compounds. The analysis of variance showed that there are significant differences $(p<0.05)$ between the different PCB-contaminated soil samples in relation to content of total $\mathrm{C}$, total $\mathrm{N}$ and total $\mathrm{P}$ in the different PCB-contaminated soil samples. This phenomenon can be attributed to the metabolic activity of the bacterial communities in the soil that contribute to the mineralization processes (Cervantes-González et al. 2019). Otherwise, the $\mathrm{C}: \mathrm{N}$ ratio determined in soil was higher in control samples when compared with the rest of the treatments (soil samples). The biochemical processes of decomposition of organic matter and mineralization that occurs in soils directly influenced the $\mathrm{C}: \mathrm{N}$ ratio. The variability of this parameter can also be attributed to nitrogen mineralization due to microbiological decomposition and the metabolization of PCBs by natural attenuation (Lladó et al. 2017).

In relation to the quantification of polychlorinated biphenyls (PCBs) as aroclor mixture (1242, 1254 and 1260) significant variations in the levels of contamination in the soil samples by each of the PCB congeners were observed (Table 2). The Hs and Hp samples recorded a high concentration of the aroclor compared to the other soil samples analyzed in this study. The concentration was higher in Hp soil possibly because the sample was collected at $50 \mathrm{~cm}$ depth where there was a higher concentration of askarel (PCBs congeners). It was also noted that aroclor 1242 had a lower concentration than the 1260 mixture in both the Hs and Hp samples, possibly 
due to volatilization or lixiviation. Similar results were reported by Jing et al. (2018) where they evaluated the distribution of PCBs in a wastewater effluent for 5 years and found that tri-, tetra-and penta-chlorinated congeners correspond to PCBs with a higher recalcitrant index at the sites of evaluation. Otherwise, the heavier aroclor (such as aroclors 1254 and 1260) are known to be recalcitrant to volatilization, and to aerobic degradation, in natural settings. It has been reported that this type of PCBs congeners persist in contaminated soils despite the exposure of several rain cycles (Kaya et al. 2017). For this reason, the bacterial communities that inhabit these contaminated soils play a very important role in the processes of degradation of the different PCB congeners. Several bioremediation experiments have been carried out and in which the efficiency of bacterial strains in the degradation of recalcitrant toxic compounds, such as PCBs, has been demonstrated. For instance, HatamianZarmi et al. (2009) evaluated the aerobic PCB degradation by Pseudomonas aeruginosa TMU56 isolated from soil that had been contaminated with electrical transformer fluid (askarel) for over 35 years. This bacterial strain was capable of decomposing PCB congeners, such as aroclor 1242 .

Regarding the diversity and composition of the bacterial community that inhabit the soils contaminated by PCBs, significant variations were observed in relation to the number of OTUs identified (Fig. 1) and also in the different indices of diversity and richness (Table 3 ) that were estimated. Despite the high concentrations of PCBs congeners (122.39 mg L${ }^{-1}$ of aroclor mixtures) contained in Hs and Hp soils, a greater number of OTUs were determined (3063 and 4489, respectively) compared to soil samples F and A (contaminated in-vitro with $100 \mathrm{mg} \mathrm{L}^{-1}$ of aroclor mixture). In the case of the sample Hp showed a greater relative abundance of Proteobacteria (23.0\%), Acidobacteria (16.0\%), Firmicutes (23.0\%), Actinobacteria (7.4\%) and Verrucomicrobia (3.3\%). Each of these phyla group an important diversity of bacterial species with biological features to tolerate and degrade toxic compounds, such as PCBs. Both, the Chao index as well as the ACE confirmed the increasing diversity in the contaminated soil, especially in Hp soil compared to the other samples. It has been detected that persistent organic pollutants (POPs) can accumulate in sediments and soils for a long time and potentially influence on the composition and diversity of bacterial communities (Sun et al. 2012). Then in these contaminated soils xenobiotic become limiting abiotic factors that exert selective pressure on microbial communities, altering the abundance and diversity of bacterial species (Bent et al. 2007). Paissé et al. (2008) studied the structure of bacterial communities along a gradient hydrocarbon contamination in coastal sediment. These authors indicated that bacterial community structure was obviously associated with the gradient of oil contamination. Our results, indicate that chemical contamination reduces bacterial richness and this pattern is in accordance with ecological theories that predict multiple stressors lead to decreased diversity, due to the inability of certain individuals to develop tolerance (Vinebrooke et al. 2004).

Metagenomic analysis based on 16S rRNA gene sequencing allowed the identification of nine different bacterial phyla in the soils evaluated (Fig. 1). Bacterial phylotypes grouped in the phyla Proteobacteria, Firmicutes, Actinobacteria and Verrucomicrobia were identified in soil samples Hs and Hp contaminated with PCBs. In these soils, Proteobacteria was the phylum that recorded the highest relative abundance. Several of these bacterial phyla have been isolated from different environments and a wide diversity of bacteria affiliated with these phyla have shown high capacity to tolerate and degrade PCBs. As is the case of Burkholderia xenovorans (member of Betaproteobacteria), a bacterium isolated from an acidic PCB-polluted soil showed high capacity to degrade this recalcitrant toxic chemical compound (Nogales et al. 2001). Also, Aguirre et al. (2007) studied the diversity of bacteria associated with the rhizospheric soil of plants and found that member of Betaproteobacteria had a high abundance mainly in soils contaminated with PCBs.

With respect to comparisons made with $\mathrm{F}$ and $\mathrm{A}$ soils, the most abundant and contrasting bacterial phyla with anthropogenic soils $\mathrm{Hs}$ and $\mathrm{Hp}$ were Actinobacteria, Bacteroidetes and Chloroflexi. The Actinobacteria and Bacteroidetes have been identified in marine sediments contaminated by PCBs (Sun et al. 2013). Regarding the dechlorination processes of PCBs, Matturro et al. (2015) evaluated anaerobic processes in sediments contaminated by PCBs where phylum Chloroflexi was the one that presented the greatest chlorine removal potential.

The analysis of bacterial community of contaminated soils at the genera level (Fig. 2) showed a greater relative abundance of Bacillus, Burkholderia, Candidatus, Clostridium and Solibacter in the anthropogenic Hs y Hp samples compared to F and A samples, where the genera identified had low relative abundance. In the $\mathrm{Hs}$ sample, genus Burkholderia registered the highest abundance in relation to the other genera identified. In the pioneering studies of bioremediation of contaminated soils, the genus Burkholderia has been considered one of the most important in PCB degradation, because it has specific enzymes that catalyze these complex chemical degradation reactions (Agulló et al. 2007). Bartels et al. (1999) identified the expression of the $b p h K$ gene related to biphenyl metabolism in the genome of the Burkholderia xenovorans LB400 strain and later, Denef et al. (2004) 
analyzed the metabolism of assimilation of chlorobenzoates and biphenyl by the strain LB400 through an outline of metabolic networks. Another important bacterium is the Bacillus sp. JF8, which has shown in potential for the degradation of polychlorinated biphenyl and naphthalene (Hatta et al. 2003).

In regard to the taxonomic identity of the bacterial species, the phylogenetic analysis of the $16 \mathrm{~S}$ rDNA gene sequence showed that the bacterial community isolated from soils contaminated by polychlorinated biphenyls (Table 4) included three major phylogenetic groups (Proteobacteria, Firmicutes and Flavobacteria). These phyla include a wide diversity of bacterial species that have specialized metabolisms, such as phototrophy, photoheterotrophy, and chemilithotrophy that allow them to degrade different persistent organic pollutants (POPs), including PCB congeners (Sun et al. 2013; Matturro et al. 2015; Mikolasch et al. 2019). The isolates from control soil were grouped within seven different ARDRA genomic profiles (A-A to A-G). The species grouped into the genus Bacillus, Achromobacter and Cupriavidus. The Genus Bacillus (Phylum Firmicutes) was the most abundant in this type of soil. These bacteria are metabolically versatile, chemolithotrophy and form spores as a survival strategy (Shimura et al. 1999). In the case of Hs soil sample, five rRNA morphotypes were identified. These bacteria were grouped into the genera Burkholderia, Myroides and Bacillus. The majority of isolates corresponded to the genus Burkholderia. Member of this genus are generally known for their ability to produce exopolysaccharide, which aid to alleviate the negative effect of highly toxic pollutants. Burkholderia have clusters of $b p h$ genes in their genome that give it the biochemical capacity to degrade biphenyl/PCB (Witzig et al. 2006). In the soil sample $\mathrm{Hp}$, there were three different bacterial species that corresponded to the genera Burkholderia and Bacillus. The strains DCB07 had $97.0 \%$ of genetic to Burkholderia anthina MYSP113, while strains DCB08 showed 95.0\% similarity to B. vietnamiensis BU97 and DCB12 had $98.3 \%$ similarity to Bacillus anthracis. The ability to degrade PCBs by Burkholderia, it has already been documented (Bartels et al. 1999, Denef et al. 2004; Agulló et al. 2007). It oxidizes more than 20 PCB congeners including some with 4, 5 and 6 chlorine substitutions on the biphenyl rings. This bacterium is characterized by having $b p h$ genes that encode enzymes that participate in the biphenyl degradation pathway. Also, Bacillus have been reported as PCB-degrading bacteria. For instance, thermophilic Bacillus sp. JF8 showed degradation of PCB congeners including tetra- and penta-chlorobiphenyl and naphthalene (Hatta et al. 2003) and the Bacillus cereus JP12 that had the capacity to degrade decabromodiphenyl ether (Lu et al. 2013).
Regarding the soil samples $\mathrm{F}$ and $\mathrm{A}$, which were contaminated in vitro by mixtures of aroclor, different bacterial species were identified. In sample F, five different ARDRA morphotypes were identified and grouped into the genera Acinetobacter, Kosakonia, Comamonas, Enterobacter and Staphylococcus. All of these bacteria have been recognized for their ability to PCBs and other highly chlorinated chemical compounds. As the case of Comamonas testosteroni who had the ability to degrade more than 95\% of PCBs. Also, Qiu et al. (2015) showed that C. testosteroni can degrade decachlorobiphenyl (PCB209) in cold conditions. In sample A, the isolates were affiliated to the Acinetobacter, Burkholderia, Comamonas and Enterobacter genera. These bacteria have genetic characteristics for potential degradation of PCBs. Liang et al. (2014) identified high abundance of Acinetobacter in sediments contaminated by PCBs where there was a dechlorination of these contaminants. Also, Enterobacter sp. LY402 isolated from polluted soil efficiently degrade PCBs under aerobic conditions, where biphenyl dioxygenase is the key enzyme in the PCBs biodegradation process (Cao et al. 2011).

PCA analysis based on the relative abundance of the different bacterial phylotypes (Fig. 3) corroborated the effect of the PCB contaminant in the different samples studied. Samples Hs and Hp had a marked separation with samples $\mathrm{F}$ and $\mathrm{A}$, possibly due to the effect of concentration and exposure time of PCB. In the soils Hp and Hs anthropogenically contaminated by high concentrations of PCBs, significant variations were observed in some parameters related to fertility. Total $\mathrm{C}$, total N, and total P and mainly SOM influenced in the functionality of the biogeochemical cycles that in turn favored the increase in the relative abundance of oligotrophic bacteria, grouped in the Phyla Firmicutes, Verrucomicrobia and Plantomycetes. While samples F and A were related to copiotrophic species, grouped into the phyla Actinobacteria and Proteobacteria. The high concentrations of the aroclor mixtures influenced the bacterial communities by exerting selective pressure, in such a way that only those bacterial species with specialized metabolism survive in these extreme conditions. This selection process is usually variable with respect to the PCB exposure time in the affected soils. In this condition, bacteria have the ability to use biphenyls as a source of $C$ and carry out degradation and mineralization processes through a variety of biochemical pathways, thereby establishing new abiotic conditions that influence diversity and structure of bacterial communities in the ecosystem (Mulligan and Yong 2004). Mikolasch et al. (2019) studied the effect of the diversity of microorganisms in soils contaminated by PCBs, finding dominant bacteria that metabolize macromolecules, making them assimilable compounds for 
other bacteria that influence the degradation of recalcitrant contaminants. However, it is important to consider that in contaminated soils, fungi and other microorganisms play an important role in the degradation of toxic chemical compounds.

Principal component analysis allowed establishing a correlation between the characteristics of soils contaminated by PCBs with respect to the specific abundances of the different phylotypes identified (Fig. 4). The anthropogenic samples were grouped ( $\mathrm{PC} 1$ became mostly negative) and is related to the concentration of aroclor 1260 containing the most recalcitrant congeners of PCBs (Wahlang et al. 2014) and the C:N ratio that is influenced by the breakdown of microbial waste and cellular respiration that indicates the presence of bacterial metabolism despite the presence of the contaminant (Wu et al. 2017), while samples $\mathrm{F}$ and A had a mostly positive $\mathrm{PC} 1$ with the rest of the soil parameters (total $\mathrm{N}$, total C, total $\mathrm{P}$, $\mathrm{pH}$ and organic matter) relating it to the aroclor mixtures 1242 and 1254 that correspond to the easiest assimilation congeners for bacterial metabolism (Martinez 2010). This indicates the importance of different nutrients for bacterial metabolic activities focused on the assimilation of pollutants and the effect on relative abundances (in the case of soils $\mathrm{F}$ and $\mathrm{A}$ ) and as the nutrients are depleted by bacteria with oligotrophic characteristics and with the potential to assimilate and metabolize PCBs, they play an important and crucial role in natural attenuation processes for the remediation of soils contaminated by PCBs.

In this study, a wide diversity and abundance of bacterial species grouped in the phyla Proteobacteria, Firmicutes and Flavobacteriia were identified in the bacterial communities that inhabit soils contaminated by high concentrations of PCBs. Acinetobacter, Bacillus, Burkholderia and Comamonas were the genera with the highest abundance, both in samples collected in anthropogenically contaminated $\mathrm{Hs}$ and $\mathrm{Hp}$ soils, as well as in those samples contaminated in vitro by PCBs, this according to the indices of abundance and diversity using both cultivable and non-cultivable approaches. The relative abundance of some species varied significantly as the PCB content in the soils increased. The bacterial communities correlated positively with some chemical parameters (mainly with organic matter) and there was also a relationship with $\mathrm{pH}$, total $\mathrm{C}$, total $\mathrm{N}$ and total $\mathrm{P}$, which influences bacterial metabolic processes and also the mineralization of organic matter and possibly of the PCBs (as C source). Several of the isolated strains had genetic similarity with bacterial species, such as Bacillus cereus, Comamonas testosteroni and Burkholderia cepacia who possess a cluster of bph genes involved in PCB/ biphenyl degradation and for this reason, these bacteria become important biotechnologies for use in programs aimed at the bioremediation of soils contaminated by PBC through biostimulation and bioaugmentation processes.

\section{Supplementary information}

Supplementary information accompanies this paper at https://doi. org/10.1186/s13568-020-01058-8.

Additional file 1: Table S1. Geographical location of sampling sites.

\section{Acknowledgements}

We thank Posgrado of Ingenieria Bioquímica-ITTG and CONAcyT a fellowship to A. We thank Leonor Madero of SC-laboratory for technical assistance.

\section{Authors' contributions}

CIRM, and AZR performed laboratory experiments and data analysis. RMG, JJVM and MAVG contributed new reagents and analytical tools. DCV and RRR data analysis. EMR, VMRV and AZR wrote the manuscript. All authors read and approved the manuscript.

\section{Funding}

Zenteno-Rojas (590686), for the scholarship granted to pursue a doctorate. Financial support was from Tecnológico Nacional de México 6841.18-P.

\section{Availability of data and materials}

We admit availability of data and material.

\section{Ethics approval and consent to participate}

This article does not contain any studies with human participants or animals performed by any of the authors. We declare consent to participate.

\section{Consent for publication}

We declare consent to publication.

\section{Competing interests}

The authors declare that they have no conflict of interest.

\section{Author details}

1 Tecnológico Nacional de México/IT de Tuxtla Gutiérrez, Carretera Panamericana Km, 1080, CP 29050 Tuxtla Gutiérrez, Chiapas, Mexico. ${ }^{2}$ Centro de Ciencias Genómicas, Universidad Nacional Autónoma de México, Av, Universidad s/n, Col. Chamilpa, 62210 Cuernavaca, Morelos, Mexico.

Received: 17 June 2020 Accepted: 2 July 2020

Published online: 10 July 2020

\section{References}

Aguirre DC, Martín M, Karlson U, Rivilla R (2007) Changes in bacterial populations and in biphenyl dioxygenase gene diversity in a polychlorinated biphenyl-polluted soil after introduction of Willow trees for rhizoremediation. Appl Environ Microbiol 73(19):6224-6232. https://doi.org/10.1128/ AEM.01254-07

Agulló L, Cámara B, Martínez P, Latorre V, Seeger M (2007) Response to (chloro) biphenyls of the polychlorobiphenyl-degrader Burkholderia xenovorans LB400 involves stress proteins also induced by heat shock and oxidative stress. FEMS Microbiol Lett 267(2):167-175. https://doi.org/10.111 1/j.1574-6968.2006.00554.x

Altschul SF, Gish W, Miller W, Myers EW, Lipman DJ (1990) Basic local alignment search tool. J Mol Biol 215(3):403-410. https://doi.org/10.1006/ jmbi.1990.9999

AOAC (1996) Official methods of analysis of AOAC international (16th ed., Vol.1). Gaithersburg: AOAC International. ISBN: 0935584544

Bartels F, Backhaus S, Moore ERB, Timmis KN, Hofer B (1999) Occurrence and expression of glutathione- S-transferase-encoding bphK genes in Burkholderia sp. strain LB400 and other biphenyl-utilizing bacteria. 
Microbiology 145(10):2821-2834. https://doi.org/10.1099/00221 287-145-10-2821

Bent SJ, Pierson JD, Forney L, Danovaro R, Luna GM, Dell'Anno A, Pietrageli B (2007) Measuring species richness based on microbial community fingerprints: the emperor has no clothes. Appl Environ Microbiol 73(7):23992401. https://doi.org/10.1128/AEM.02383-06

Birnbaum LS (1995) Developmental effects of dioxins. Environ Health Perspect 103(7):89-94. https://doi.org/10.1289/ehp.95103s789

Bremner JM (1996) Total nitrogen. In: Sparks DL (ed) Methods of soil analysis chemical methods. Part 3. Soil science society of America inc. American Society of Agronomy Inc., Madison, pp 1085-1122

Cao YM, Xu L, Jia LY (2011) Analysis of PCBs degradation abilities of biphenyl dioxygenase derived from Enterobacter sp. LY402 by molecular simulation. N Biotechnol 29(1):90-98. https://doi.org/10.1016/j.nbt.2011.08.005

Caporaso JG, Kuczynski J, Stombaugh J, Bittinger K, Bushman FD, Costello EK, Fierer N, Peña AG, Goodrich JK, Gordon Jl, Huttley GA, Kelley ST, Knights D, Koenig JE, Ley RE, Lozupone CA, McDonald D, Muegge BD, Pirrung M, Reeder J, Sevinsky JR, Turnbaugh PJ, Walters WA, Widmann J, Yatsunenko T, Zaneveld J, Knight R (2010a) QIIME allows analysis of high-throughput community sequencing data. Nat Methods 7(5):335-336. https://doi. org/10.1038/nmeth.f.303

Caporaso JG, Bittinger K, Bushman FD, DeSantis TZ, Andersen GL, Knight R (2010b) PyNAST: a flexible tool for aligning sequences to a template alignment. Bioinformatics 26(2):266-267. https://doi.org/10.1093/bioin formatics/btp636

Ceja-Navarro JA, Rivera-Orduña FN, Patiño-Zúñiga L, Vila-Sanjurjo A, Crossa J, Govaerts B, Dendooven L (2010) Phylogenetic and multivariate analyses to determine the effects of different tillage and residue management practices on soil bacterial communities. Appl Environ Microbiol 76(11):3685-3691. https://doi.org/10.1128/AEM.02726-09

Cervantes-González E, Guevara-García MA, García-Mena J, Ovando-Medina VM (2019) Microbial diversity assessment of polychlorinated biphenyl-contaminated soils and the biostimulation and bioaugmentation processes. Environ Monit Assess 191(2):118. https://doi.org/10.1007/ s10661-019-7227-4

Denef VJ, Park J, Tsoi TV, Rouillard JM, Zhang H, Wibbenmeyer JA, Verstraete W, Gulari E, Hashsham SA, Tiedje JM (2004) Biphenyl and benzoate metabolism in a genomic context: outlining genome-wide metabolic networks in Burkholderia xenovorans LB400. Appl Environ Microbiol 70(8):49614970. https://doi.org/10.1128/AEM.70.8.4961-4970.2004

Di Lenola M, Caracciolo AB, Grenni P, Ancona V, Rauseo J, Laudicina VA, Uricchio VF, Massacci A (2018) Effects of apirolio addition and alfalfa and compost treatments on the natural microbial community of a historically PCB-contaminated soil. Water Air Soil Pollut 229:143. https://doi. org/10.1007/s11270-018-3803-4

Dudášová H, Derco J, Sumegová L, Dercová K, Lászlová K (2016) Removal of polychlorinated biphenyl congeners in mixture Delor 103 from wastewater by ozonation vs/and biological method. J Hazard Mater 321:54-61. https://doi.org/10.1016/j.jhazmat.2016.08.077

Edgar RC (2010) Search and clustering orders of magnitude faster than BLAST. Bioinformatics 26(19):2460-2461. https://doi.org/10.1093/bioinformatics/ bta461

Furukawa K, Fujihara H (2008) Microbial degradation of polychlorinated biphenyls: biochemical and molecular features. J Biosci Bioeng 105(5):433-449. https://doi.org/10.1263/jbb.105.433

Goldey ES, Kehn LS, Lau C, Rehnberg GL, Crofton KM (1995) Developmental exposure to polychlorinated biphenyls (Aroclor 1254) reduces circulating thyroid hormone concentrations and causes hearing deficits in rats. Toxicol Appl Pharmacol 135(1):77-88. https://doi.org/10.1006/taap.1995.1210

Haas BJ, Gevers D, Earl AM, Feldgarden M, Ward DV, Giannoukos G, Ciulla D, Tabbaa D, Highlander SK, Sodergren E (2011) Chimeric $16 \mathrm{~S}$ rRNA sequence formation and detection in Sanger and 454-pyrosequenced PCR amplicons. Genome Res 21(3):494-504. https://doi.org/10.1101/ gr.112730.110

Hatamian-Zarmi A, Shojaosadati SA, Vasheghani-Farahani E, Hosseinkhani S, Emamzadeh A (2009) Extensive biodegradation of highly chlorinated biphenyl and Aroclor 1242 by Pseudomonas aeruginosa TMU56 isolated from contaminated soils. Int Biodeter Biodegr 63(6):788-794. https://doi. org/10.1016/j.ibiod.2009.06.009

Hatta T, Mukerjee-Dhar G, Damborsky J, Kiyohara H, Kimbara K (2003) Characterization of a novel thermostable Mn (II)-dependent 2,3-dihydroxybiphenyl 1,2-dioxygenase from a polychlorinated biphenyland naphthalene degrading Bacillus sp. JF8. J Biol Chem 278(24):2148321492. https://doi.org/10.1074/jbc.M210240200

Hayes MA, Safe SH, Armstrong D, Cameron RG (1985) Influence of cell proliferation on initiating activity of pure polychlorinated biphenyls and complex mixtures in resistant hepatocyte in vivo assays for carcinogenicity. J Natl Cancer Inst 74(5):1037-1041. https://doi.org/10.1093/jnci/74.5.1037

Horváthová H, Lászlová K, Dercová K (2018) Bioremediation of PCB-contaminated shallow river sediments: the efficacy of biodegradation using individual bacterial strains and their consortia. Chemosphere 193:270-277. https://doi.org/10.1016/j.chemosphere.2017.11.012

Hu D, Hornbuckle KC (2010) Inadvertent polychlorinated biphenyls in commercial paint pigments. Environ Sci Technol 44(8):2822-2827. https://doi. org/10.1021/es902413k

Hu D, Martinez A, Hornbuckle KC (2011) Sedimentary records of non-Aroclor and Aroclor PCB mixtures in the Great Lakes. J Great Lakes Res 37(2):359364. https://doi.org/10.1016/j.jglr.2011.03.001

Jing R, Fusi S, Chan A, Capozzi S, Kjellerup BV (2018) Distribution of polychlorinated biphenyls in effluent from a large municipal wastewater treatment plant: potential for bioremediation. J Environ Sci 78:42-52. https:// doi.org/10.1016/j.jes.2018.06.007

Jugder BE, Ertan H, Bohl S, Lee M, Marquis CP, Manefield M (2016) Organohalide respiring bacteria and reductive dehalogenases: key tools in organohalide bioremediation. Front Microbiol 7:249. https://doi.org/10.3389/ fmicb.2016.00249

Kaya D, Imamoglu I, Sanin FD, Sowers KR (2017) A comparative evaluation of anaerobic dechlorination of PCB-118 and Aroclor 1254 in sediment microcosms from three PCB-impacted environments. J Hazard Mater 341:328-335. https://doi.org/10.1016/j.jhazmat.2017.08.005

Koeuth T, Versalovic J, Lupski JR (1995) Differential subsequence conservation of interspersed repetitive Streptococcus pneumoniae BOX elements in diverse bacteria. Genome Res 5:408-418. https://doi.org/10.1101/ gr.5.4.408

Larkin MA, Blackshields G, Brown NP, Chenna R, McGettigan PA, Mc William H, Valentin F, Wallace IM, Wilm A, Lopez R, Thompson JD, Gibson TJ, Higgins DG (2007) Clustal W and Clustal X version 2.0. Bioinformatics 23(21):29472948. https://doi.org/10.1093/bioinformatics/btm404

Liang Y, Martinez A, Hornbuckle KC, Mattes TE (2014) Potential for polychlorinated biphenyl biodegradation in sediments from Indiana Harbor and Ship Canal. Int Biodeterior Biodegradation 89:50-57. https://doi. org/10.1016/j.ibiod.2014.01.005

Lladó S, López-Mondéjar R, Baldrian P (2017) Forest soil bacteria: diversity, involvement in ecosystem processes, and response to global change. Microbiol Mol Biol Rev. https://doi.org/10.1128/MMBR.00063-16

Lu M, Zhong-Zhi Z, Xue-Jiao W, Yu-Xin X, Xiao-Li S, Min Z, Jing-Xiu W (2013) Biodegradation of decabromodiphenyl ether (BDE-209) by a metal resistant strain, Bacillus cereus JP12. Bioresour Technol 149:8-15. https://doi org/10.1016/j.biortech.2013.09.040

Martinez A (2010) Release of polychlorinated biphenyl congeners in a contaminated harbor and canal. Ph.D. Dissertation. Department of Civil \& Environmental Engineering, The University of lowa, lowa. https://doi. org/10.17077/etd.x60wtw44

Matturro B, Carla U, Paola G, Anna BC, Simona R (2015) Polychlorinated biphenyl (PCB) anaerobic degradation in marine sediments: microcosm study and role of autochthonous microbial communities. Environ Sci Pollut Res 23(13):12613-12623. https://doi.org/10.1007/s11356-015-4960-2

Matturro B, Carla U, Simona R (2016) Microbiome dynamics of a polychlorobiphenyl (PCB) historically contaminated marine sediment under conditions promoting reductive dechlorination. Front Microbiol 7:1502. https:// doi.org/10.3389/fmicb.2016.01502

Mikolasch A, Donath M, Reinhard A, Herzer C, Zayadan B, Urich T, Schauer F (2019) Diversity and degradative capabilities of bacteria and fungi isolated from oil-contaminated and hydrocarbon-polluted soils in Kazakhstan. Appl Microbiol Biotechnol 103(17):7261-7274. https://doi. org/10.1007/s00253-019-10032-9

Mulligan CN, Yong RN (2004) Natural attenuation of contaminated soils. Environ Int 30:587-601. https://doi.org/10.1016/j.envint.2003.11.001

Nogales B, Moore ERB, Llobet-Brossa E, Rossello-Mora R, Amann R, Timmis KN (2001) Combined use of 16S ribosomal DNA and 16S rRNA to study the bacterial community of polychlorinated biphenyl-polluted 
soil. Appl Environ Microbiol 67(4):1874-1884. https://doi.org/10.1128/ AEM.67.4.1874-1884.2001

Nogales B, Lanfranconi MP, Piña-Villalonga JM, Bosch R (2011) Anthropogenic perturbations in marine microbial communities. FEMS Microbiol Rev 35(2):275-298. https://doi.org/10.1111/j.1574-6976.2010.00248.x

NOM-133-SEMARNAT-2015. Protección Ambiental Bifenilos Policlorados (BPC's), Especificaciones de Manejo. Mexico. 23 de Febrero de 2016

Nuzzo A, Negroni A, Giulio Z, Fabio F (2017) Identification of two organohalide-respiring Dehalococcoidia associated to different dechlorination activities in PCB-impacted marine sediments. Microb Cell Fact 16:127. https://doi.org/10.1186/s12934-017-0743-4

Pachiadaki MG, Lykousis V, Stefanou EG, Kormas KA (2010) Prokaryotic community structure and diversity in the sediments of an active submarine mud volcano (Kazan mud volcano, East Mediterranean Sea. FEMS Microbiol Ecol 7283:429-444. https://doi.org/10.1111/j.1574-6941.2010.00857.x

Paissé S, Coulon F, Goñi-Urriza M, Peperzak L, McGenity TJ, Duran R (2008) Structure of bacterial communities along a hydrocarbon contamination gradient in a coastal sediment. FEMS Microbiol Ecol 66(2):295-305. https ://doi.org/10.1111/j.1574-6941.2008.00589.x

Passatore L, Rossetti S, Juwarkar AA, Massacci A (2014) Phytoremediation and bioremediation of polychlorinated biphenyls (PCBs): state of knowledge and research perspectives. J Hazard Mater 278:189-202. https://doi. org/10.1016/j.jhazmat.2014.05.051

Pop RP, Wenzhöfer F, Ramette A, Felden J, Boetius A (2015) Spatial scales of bacterial community diversity at cold seeps (Eastern Mediterranean Sea). ISME J 9(6):1306-1318. https://doi.org/10.1594/PANGAEA.830241

Qiu L, Wang H, Wang X (2015) Isolation and characterization of a cold-resistant PCB209-degrading bacterial strain from river sediment and its application in bioremediation of contaminated soil. J Environ Sci Health A Tox Hazard Subst Environ Eng 51(3):204-212. https://doi.org/10.1080/10934 529.2015.1094324

Quero GM, Cassin D, Botter M, Perini L, Luna GM (2015) Patterns of benthic bacterial diversity in coastal areas contaminated by heavy metals polycyclic aromatic hydrocarbons (PAHs) and polychlorinated biphenyls (PCBs). Front Microbiol 6:1053. https://doi.org/10.3389/fmicb.2015.01053

Robertson LW, Hansen LG (2015) PCBs: recent advances in environmental toxicology and health effects. University Press of Kentucky, Lexington. pp. ix-x. JSTOR, www.jstor.org/stable/j.ctt130j2pw.3

Sager DB, Girard DM (1994) Long-term effects on reproductive parameters in female rats after translational exposure to PCBs. Environ Res 66(1):52-76. https://doi.org/10.1006/enrs.1994.1044

Shimura M, Mukerjee-Dhar G, Kimbara K, Nagato H, Kiyohara H, Hatta T (1999) Isolation and characterization of a thermophilic Bacillus sp. JF8 capable of degrading polychlorinated biphenyls and naphthalene. FEMS Microbiol Lett 178(1):87-93. https://doi.org/10.1111/j.1574-6968.1999.tb13763.x

Silberhorn EM, Glauert HP, Robertsson LW (1990) Carcinogenicity of polyhalogenated biphenyls: PCBs and PBBs. Crit Rev Toxicol 20(6):440-496. https:// doi.org/10.3109/10408449009029331

Soil Survey Staff (2010) Keys to soil Taxonomy, 11th edn. USDA, National Resources Conservation Service, National Soil Survey Center, Lincoln

Sun MY, Dafforn KA, Brown MV, Johnston EL (2012) Bacterial communities are sensitive indicators of contaminant stress. Mar Pollut Bull 64(5):10291038. https://doi.org/10.1016/j.marpolbul.2012.01.035
Sun MY, Dafforn KA, Johnston EL, Brown MV (2013) Core sediment bacteria drive community response to anthropogenic contamination over multiple environmental gradients. Environ Microbiol 15(9):2517-2531. https:// doi.org/10.1111/1462-2920.12133

Tamura K, Peterson D, Peterson N, Stecher G, Nei M, Kumar S (2011) MEGA 5: molecular evolutionary genetics analysis using maximum likelihood, evolutionary distance, and maximum parsimony methods. Mol Biol Evol 28(10):2731-2739. https://doi.org/10.1093/molbev/msr121

Tehrani R, Van AB (2014) Hydroxylated polychlorinated biphenyls in the environment: sources, fate, and toxicities. Environ Sci Pollut Res Int 21(10):6334-6345. https://doi.org/10.1007/s11356-013-1742-6

Tryphonas H, Luster MI, White KL Jr, Naylor PH, Erdos MR, Burleson GR, Germolec D, Hodgen M, Hayward S, Arnold DL (1991) Effect of chronic exposure of PCB (Aroclor 1254) on specific and nonspecific immune parameters in the rhesus (Macaca mulatta) monkeys. Int J Immunopharmacol 13(6):639-648. https://doi.org/10.1016/0192-0561(91)90176-8

Vinebrooke DR, Cottingham LK, Norberg MS, Dodson IS, Maberly CS, Sommer U (2004) Impacts of multiple stressors on biodiversity and ecosystem functioning: the role of species co-tolerance. Oikos 104(3):451-457. https ://doi.org/10.1111/j.0030-1299.2004.13255.x

Wahlang B, Falkner KC, Clair HC, Al-Eryani C, Prough RA, States JC, Coslo DM, Omiecinski CJ, Cave M (2014) Human receptor activation by aroclor 1260, a polychlorinated biphenyl mixture. Toxicol Sci 140(2):283-297. https:// doi.org/10.1093/toxsci/kfu083

Wang Q, Garrity GM, Tiedje JM, Cole JR (2007) Naïve bayesian classifier for rapid assignment of rRNA sequences into the new bacterial taxonomy. Appl Environ Microb 73(16):5261-5267. https://doi.org/10.1128/AEM.00062-07

Weisburg WG, Barns SM, Pelletier DA, Lane DJ (1991) 16S ribosomal DNA amplification for phylogenetic study. J Bacteriol 173(2):697-703. https:// doi.org/10.1128/jb.173.2.697-703.1991

Witzig R, Junca H, Hecht HJ, Pieper GH (2006) Assessment of toluene/biphenyl dioxygenase gene diversity in benzene-polluted soils: links between benzene biodegradation and genes similar to those encoding isopropylbenzene dioxygenases. Appl Environ Microbiol 72(5):3504-3514. https://doi. org/10.1128/AEM.72.5.3504-3514.2006

Wu W, Dong C, Wu C, Liu X, Wub Y, Chen X, Yua S (2017) Ecological effects of soil properties and metal concentrations on the composition and diversity of microbial communities associated with land us patterns in an electronic waste recycling region. Sci Total Environ 601-602:57-65. https ://doi.org/10.1016/j.scitotenv.2017.05.165

Zenteno-Rojas A, Martinez-Romero E, Rincón-Molina C, Ruíz-Valdiviezo VM, Meza-Gordillo R, Villalobos-Maldonado JJ, Rincón-Rosales R (2019) Removal of high concentrations decachlorobiphenyl of earthworm Eisenia fetida and its symbiotic bacteria in a vermicomposting system. Water Air Soil Pollut 230:1 16. https://doi.org/10.1007/s11270-019-4170-5

\section{Publisher's Note}

Springer Nature remains neutral with regard to jurisdictional claims in published maps and institutional affiliations.

\section{Submit your manuscript to a SpringerOpen ${ }^{\circ}$ journal and benefit from:}

- Convenient online submission

- Rigorous peer review

- Open access: articles freely available online

- High visibility within the field

- Retaining the copyright to your article

Submit your next manuscript at springeropen.com 